\title{
Isolation and Characterization of Dinochrome $A$ and $B$, Anti-carcinogenic Active Carotenoids from the Fresh Water Red Tide Peridinium bipes
}

\author{
Takashi MaOKA, ${ }^{*, a, 1)}$ Miyuki Tsushima, ${ }^{a}$ and Hoyoku Nishino ${ }^{b}$ \\ ${ }^{a}$ Kyoto Pharamceutical University; Misasagi, Yamashina-ku, Kyoto 607-8412, Japan: and ${ }^{b}$ Department of Biochemistry, \\ Kyoto Prefectural University of Medicine; Kawaramachi-Hirokouji, Kamigyo-ku, Kyoto 602-0841, Japan. \\ Received August 15, 2002; accepted September 26, 2002
}

Two epimeric carotenoids, named dinochromes A (2) and B (3), were isolated from the fresh water red tide Peridinium bipes, as anti-carcinogenic compounds. The stereostructure of dinochrome $A$ and $B$ were characterized to be $\left(3 S, 5 R, 6 R, 3^{\prime} S, 5^{\prime} R, 8^{\prime} R\right)$ - and $\left(3 S, 5 R, 6 R, 3^{\prime} S, 5^{\prime} R, 8^{\prime} S\right)-5^{\prime}, 8^{\prime}$-epoxy-6,7-didehydro-5,6,5', $8^{\prime}$-tetrahydro- $\beta, \beta$ carotene-3,5,3'-triol 3-O-acetate, respectively by ${ }^{11} \mathrm{H}$ - and ${ }^{13} \mathrm{C}-\mathrm{NMR}$, and circular dichroism (CD) data. Dinochromes A (2) and B (3) inhibit 12-O-tetradecanoyl phorbol 13-acetate (TPA)-stimulated ${ }^{32} \mathrm{P}$-incorporation into the phosholipids of HeLa cells. Furthermore, dinochrome A was found to inhibit the proliferation of human malignant tumor cells, such as GOTO, OST and HeLa cells.

Key words Peridinium bipes; carotenoid; anti-carcinogenic activity; anti-tumor activity; dinochrome A; dinochrome B

Peridinin is the main carotenoid in red tide, ${ }^{2)}$ and exhibits anti-tumor and anti-carcinogenic activities. ${ }^{3,4}$ This prompted us to search for anti-carcinogenic active compounds from microalgae, and to isolate and characterize carotenoids that possess anti-carcinogenic activities from the fresh water red tide, Peridinium bipes. In this paper, we describe the isolation and the characterization of the stereostructure of two epimeric carotenoids, named dinochromes $\mathrm{A}$ and $\mathrm{B}$. We also demonstrate the inhibitory effect of these carotenoids on 12-Otetradecanoyl phorbol 13-acetate (TPA)-stimulated ${ }^{32} \mathrm{P}$-incorporation into the phosholipids of HeLa cells; a mechanism that is used in the primary screening test for anti-carcinogenic compounds. ${ }^{5)}$ Furthermore, the inhibitory effects of dinochrome $\mathrm{A}$ on human malignant tumor cells were also studied.

Isolation of Carotenoids from Peridinium bipes The fresh water red tide Peridinium bipes $(500 \mathrm{~g})$, was extracted with acetone-methanol $(7: 3)$. After evaporation of the solvent, the residue was subjected to column chromatography on silica gel and preparative HPLC on octadecyl silica (ODS). Eight carotenoids were isolated; $\beta$-carotene (1) (40.5 $\mathrm{mg}$ ), dinochrome A (2) (71.5 mg), dinochrome B (3) (13.5 $\mathrm{mg}$ ), diadinochrome A (4) (13.5 mg), diadinochrome B (5) $(1 \mathrm{mg})$, peridinin $(6)(132.5 \mathrm{mg})$, dinoxanthin $(7)(8.5 \mathrm{mg})$, and diatoxanthin $(8)(34 \mathrm{mg})$. Compounds $1,4,5,6,7$, and 8 were identified by comparing their spectral data with the values reported in the literature. ${ }^{6,7)}$

Characterization of the Stereostructure of Dinochrome A and B Compound 2 (dinochrome A) exhibited visible light absorption maxima at 400, 423, and $450 \mathrm{~nm}$. High resolution electrom impact (HR-EI)-MS gave a molecular ion at $\mathrm{m} / \mathrm{z}$ 642.4280, corresponding to the formula $\mathrm{C}_{42} \mathrm{H}_{58} \mathrm{O}_{5}$. Acetylation of 2 produced a mono acetate with a molecular ion of $m / z 684.4395$. The presence of one secondary hydroxy group, one tertiary hydroxy group and one acetoxy group in 2 was confirmed by HR-EI-MS, ${ }^{1} \mathrm{H}-,{ }^{13} \mathrm{C}-\mathrm{NMR}$ data. The remaining one oxygen is ascribed to a furanoxide group by $\left.{ }^{13} \mathrm{C}-\mathrm{NMR}(\delta 86.8,87.7)^{7}\right)$ and a characteristic EI-MS fragment ion of M-80. ${ }^{8}$ The presence of an allenic group was revealed by the characteristic ${ }^{13} \mathrm{C}$ signal at $\delta 204.4$ and the ${ }^{1} \mathrm{H}$ signal at $\delta 6.05$. ${ }^{7}$ The ${ }^{1} \mathrm{H}$ - and ${ }^{13} \mathrm{C}-\mathrm{NMR}$ data for 2 , which were assigned by double quantum filtered correlation spectroscopy (DQF-COSY), nuclear Overhauser effect spectroscopy (NOESY), heteronuclear single quantum coherence (HSQC), and heteronuclear multiple bond connectivity (HMBC), are presented in Table 1. These results revealed that the structure of 2 is $5^{\prime}, 8^{\prime}$-epoxy-6,7-didehydro-5,6,5', $8^{\prime}$ tetrahydro- $\beta, \beta$-carotene- $3,5,3^{\prime}$-triol 3-O-acetate (dinochrome). The $5^{\prime}, 8^{\prime}$-trans configuration in the furan ring was determined by the coupling constant of $J_{\mathrm{H}-7^{\prime}-\mathrm{H}-8^{\prime}}=0.7 \mathrm{~Hz}^{7,9-11)}$ and the NOESY data. NOE between $\mathrm{CH}_{3}-18^{\prime}(\delta$ 1.62) and $\mathrm{H}-8^{\prime}\left(\delta\right.$ 5.17) indicates that $\mathrm{CH}_{3}-18^{\prime}$ and $\mathrm{H}-8^{\prime}$ are located on the same side of the furan ring (Fig. 1).

Compound 3 (dinochrome B) showed the same UV-vis and EI-MS as compound 2. Acetylation of $\mathbf{3}$ also produced a mono acetate. The ${ }^{1} \mathrm{H}-$ and ${ }^{13} \mathrm{C}-\mathrm{NMR}$ data (Table 1) of $\mathbf{3}$ were consistent with the $8^{\prime}$-epimer structure of dinochrome A. ${ }^{7,9-11)}$ The coupling constant of $J_{\mathrm{H}-7^{\prime}-\mathrm{H}-8^{\prime}}=1.5 \mathrm{~Hz}$ indicated a $5^{\prime}, 8^{\prime}$-cis configuration in the furan ring. NOESY correlation between $\mathrm{CH}_{3}-18^{\prime}$ and $\mathrm{H}-8^{\prime}$ was not observed in compound 3. The absolute configurations of compounds 2 $\left(3 S, 5 R, 6 R, 3^{\prime} S, 5^{\prime} R, 8^{\prime} R\right)$ and $3\left(3 S, 5 R, 6 R, 3^{\prime} S, 5^{\prime} R, 8^{\prime} S\right)$ were determined by comparing the circular dichroism (CD) spectral data of the compounds with those of the stereoisomers of the neochromes that were reported by Marki-Fischer et al. ${ }^{11}$

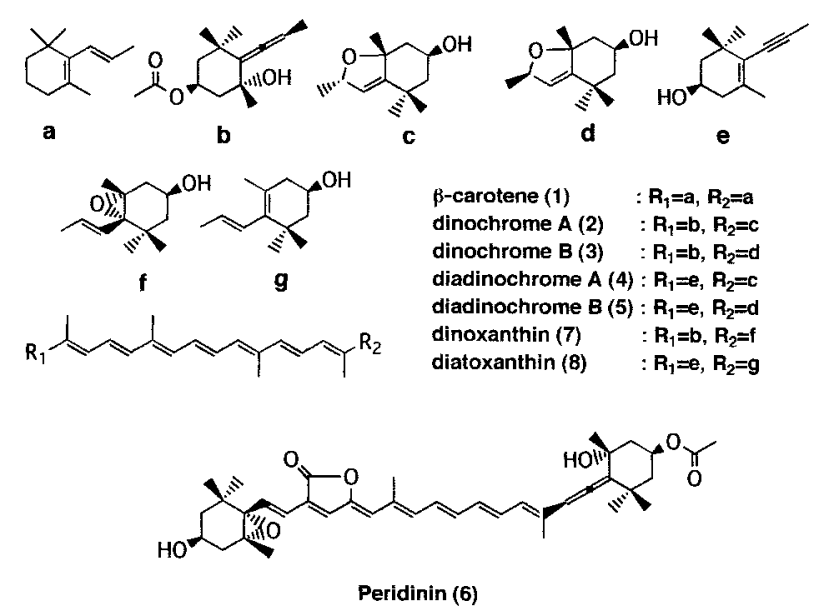


Table 1. ${ }^{1} \mathrm{H}-(500 \mathrm{MHz})$ and ${ }^{13} \mathrm{C}-\mathrm{NMR}(125 \mathrm{MHz})$ Data of Dinochrome A (2) and Dinochrome $\mathrm{B}(3)$ in $\mathrm{CDCl}_{3}$

\begin{tabular}{|c|c|c|c|c|}
\hline \multirow{3}{*}{ Position } & \multicolumn{4}{|c|}{ Compound } \\
\hline & \multicolumn{2}{|c|}{2} & \multicolumn{2}{|c|}{3} \\
\hline & $\delta{ }^{13} \mathrm{C}$ & $\delta^{1} \mathrm{H}$ mult. $(J, \mathrm{~Hz})$ & $\delta{ }^{13} \mathrm{C}$ & $\delta^{1} \mathrm{H}$ mult. $(J, \mathrm{~Hz})$ \\
\hline 1 & 35.7 & - & 35.7 & - \\
\hline \multirow[t]{2}{*}{2} & 45.4 & $\beta 1.41 \mathrm{dd}(12.0,12.0)$ & 45.4 & $\beta 1.41 \mathrm{dd}(12.0,12.0)$ \\
\hline & & $\alpha 1.91 \mathrm{dd}(12.0,4.0)$ & & $\alpha 1.91 \mathrm{dd}(12.0,4.0)$ \\
\hline 3 & 67.8 & $5.38 \mathrm{~m}$ & 67.8 & $5.38 \mathrm{~m}$ \\
\hline \multirow[t]{2}{*}{4} & 45.2 & $\beta 1.51 \mathrm{dd}(12.0,12.0)$ & 45.2 & $\beta 1.51 \mathrm{dd}(12.0,12.0)$ \\
\hline & & $\alpha 2.28$ ddd $(13.5,4.0,2.0)$ & & $\alpha 2.28$ ddd $(13.5,4.0,2.0)$ \\
\hline 5 & 72.7 & - & 72.7 & - \\
\hline 6 & 117.4 & - & 117.4 & - \\
\hline 7 & 204.4 & - & 204.4 & - \\
\hline 8 & 103.4 & $6.05 \mathrm{~s}$ & 103.4 & $6.05 \mathrm{~s}$ \\
\hline 9 & 131.7 & - & 131.7 & - \\
\hline 10 & 128.6 & $6.12 \mathrm{~d}(11.0)$ & 128.6 & $6.12 \mathrm{~d}(11.0)$ \\
\hline 11 & 124.7 & $6.54 \mathrm{dd}(15.0,11.0)$ & 124.7 & $6.54 \mathrm{dd}(15.0,11.0)$ \\
\hline 12 & 137.4 & $6.34 \mathrm{~d}(15.0)$ & 137.4 & $6.34 \mathrm{~d}(15.0)$ \\
\hline 13 & 138.0 & - & 138.0 & - \\
\hline 14 & 132.5 & $6.24 \mathrm{~m}$ & 132.5 & $6.24 \mathrm{~m}$ \\
\hline 15 & $130.0^{a)}$ & $6.62 \mathrm{~m}$ & $130.0^{a)}$ & $6.62 \mathrm{~m}$ \\
\hline 16 & 32.1 & $1.07 \mathrm{~s}$ & 32.1 & $1.07 \mathrm{~s}$ \\
\hline 17 & 28.9 & $1.35 \mathrm{~s}$ & 28.9 & $1.35 \mathrm{~s}$ \\
\hline 18 & 29.2 & $1.38 \mathrm{~s}$ & 29.2 & $1.38 \mathrm{~s}$ \\
\hline 19 & 13.9 & $1.80 \mathrm{~s}$ & 13.9 & $1.80 \mathrm{~s}$ \\
\hline 20 & 12.8 & $1.96 \mathrm{~s}$ & 12.8 & $1.96 \mathrm{~s}$ \\
\hline $\mathrm{CH}_{3}-\mathrm{CO}$ & 21.4 & $2.04 \mathrm{~s}$ & 21.4 & $2.04 \mathrm{~s}$ \\
\hline $\mathrm{CH}_{3}-\underline{\mathrm{CO}}$ & 170.4 & - & 170.4 & - \\
\hline $1^{\prime}$ & 33.7 & - & 34.2 & - \\
\hline \multirow[t]{2}{*}{$2^{\prime}$} & 46.7 & $\alpha \quad 1.52 \mathrm{dd}(14.5,3.5)$ & 47.5 & $\alpha 1.48 \mathrm{dd}(14.5,3.5)$ \\
\hline & & $\beta 1.77$ ddd $(14.0,5.0,1.5)$ & & $\beta 1.80$ ddd $(14.0,5.0,1.5)$ \\
\hline $3^{\prime}$ & 68.0 & $4.25 \mathrm{~m}$ & 68.0 & $4.25 \mathrm{~m}$ \\
\hline \multirow[t]{2}{*}{$4^{\prime}$} & 47.3 & $\alpha 1.99 \mathrm{dd}(14.0,4.0)$ & 47.5 & $\alpha 1.90 \mathrm{dd}(14.0,4.0)$ \\
\hline & & $\beta 2.13$ ddd $(14.0,4.0,1.5)$ & & $\beta 2.12$ ddd $(14.0,4.0,1.5)$ \\
\hline $5^{\prime}$ & 86.8 & - & 87.2 & - \\
\hline $6^{\prime}$ & 154.1 & - & 153.3 & - \\
\hline $7^{\prime}$ & 119.9 & $5.26 \mathrm{~d}(0.7)$ & 118.8 & $5.31 \mathrm{~d}(1.5)$ \\
\hline $8^{\prime}$ & 87.7 & 5.17 br s & 88.4 & 5.07 br s \\
\hline $9^{\prime}$ & 137.9 & - & 138.7 & - \\
\hline $10^{\prime}$ & 127.2 & $6.19 \mathrm{~d}(11.0)$ & 126.2 & $6.19 \mathrm{~d}(11.0)$ \\
\hline $11^{\prime}$ & 124.4 & $6.49 \mathrm{dd}(15.0,11.0)$ & 124.4 & $6.51 \mathrm{dd}(15.0,11.0)$ \\
\hline $12^{\prime}$ & 137.6 & $6.32 \mathrm{~d}(15.0)$ & 137.6 & $6.32 \mathrm{~d}(15.0)$ \\
\hline $13^{\prime}$ & 136.2 & - & 136.3 & - \\
\hline $14^{\prime}$ & 132.6 & $6.24 \mathrm{~m}$ & 132.6 & $6.23 \mathrm{~m}$ \\
\hline $15^{\prime}$ & $129.9^{a)}$ & $6.62 \mathrm{~m}$ & $129.9^{a)}$ & $6.62 \mathrm{~m}$ \\
\hline $16^{\prime}$ & 31.4 & $1.17 \mathrm{~s}$ & 31.2 & $1.20 \mathrm{~s}$ \\
\hline $17^{\prime}$ & 28.9 & $1.33 \mathrm{~s}$ & 28.1 & $1.35 \mathrm{~s}$ \\
\hline $18^{\prime}$ & 29.0 & $1.62 \mathrm{~s}$ & 30.6 & $1.69 \mathrm{~s}$ \\
\hline $19^{\prime}$ & 12.6 & $1.71 \mathrm{~s}$ & 13.4 & $1.80 \mathrm{~s}$ \\
\hline $20^{\prime}$ & 12.8 & $1.95 \mathrm{~s}$ & 12.8 & $1.95 \mathrm{~s}$ \\
\hline
\end{tabular}

a) Assignments may be interchangeable in each vertical column.

The CD spectra of $\mathbf{2}$ and $\mathbf{3}$ were mirror-images each other and reflected chirality at $\left.\mathrm{C}-8^{\prime} .^{12}\right)$

The planer structures of dinochrome was postulated by Johansen et al. ${ }^{6}$ ) This is the first report on the characterization of the stereostructure of dinochromes by NMR and CD spectral data and we named dinochrome A for $\mathbf{2}$ and dinochrome $\mathrm{B}$ for $\mathbf{3}$, respectively. Dinochromes A and B were assumed to be acidic-catalyzed epoxy-furanoxide rearrangement products of dinoxanthin in $P$. bipes.

Anti-carcinogenic Activity of Carotenoids from $P$. bipes The in vitro anti-carcinogenic activity of dinochrome A (2), dinochrome B (3), peridinin (6), and diatoxanthin (8) isolated from $P$. bipes was evaluated by assessing the inhibitory effect on TPA-stimulated ${ }^{32} \mathrm{P}$-incorporation into the phosholipids of HeLa cells. ${ }^{5)}$ All of the carotenoids investigated inhibited this incorporation potently at a concentration of $25 \mu \mathrm{g} / \mathrm{ml}$, as shown in Table 2. Dinochrome A and dinochrome B were found to be more effective than peridinin that has been studied in cancer prevention experiments using animal models. ${ }^{3,4}$ Among the carotenoids examined, ${ }^{13)}$ dinochrome A showed the strongest inhibitory activity on TPA-stimulated ${ }^{32} \mathrm{P}$-incorporation into the phosholipids of HeLa cells. Some carotenoids exhibit anti-carcinogenic and anti-tumor activities. ${ }^{3,4,13,14)}$ Thus, the inhibitory effects of dinochrome A on the proliferation of human malignant cells such as GOTO (neuroblastoma), OST (osteosarcoma) and HeLa cells were 


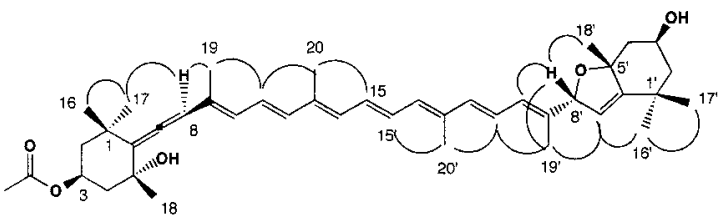

Dinochrome A (2)

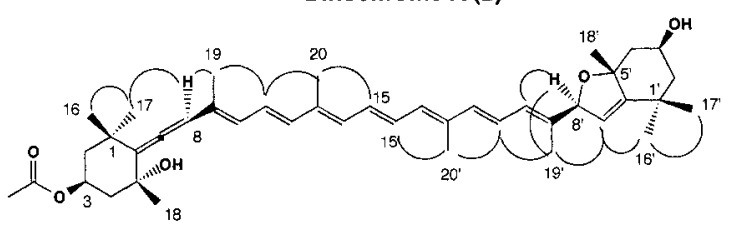

Dinochrome B (3) $\bigcirc$ NOESY correlation

Fig. 1. Structures and Some Key NOE Correlations of Dinochrome A (2) and Dinochrome B (3)

Table 2. Effect of Red Tide Carotenoids on TPA-Stimulated ${ }^{32}$ P-Incorporation into the Phospholipids of HeLa Cells

\begin{tabular}{lc}
\hline \hline Carotenoid & Inhibition \% \\
\hline Dinochrome A (2) & 72.1 \\
Dinochrome B (3) & 35.0 \\
Peridinin (6) & 28.2 \\
Diatoxanthin (8) & 48.2
\end{tabular}

TPA: $50 \mathrm{~nm}$, Carotenoid: $25 \mu \mathrm{g} / \mathrm{ml}$.

Table 3. Inhibitory Effects of Dinochrome A (2) on the Proliferation of Human Malignant Tumor Cells

\begin{tabular}{cccc}
\hline \hline \multirow{2}{*}{ Type of cells } & \multicolumn{3}{c}{ Viable cell number $\left(\times 10^{4} / \mathrm{dish}\right)$} \\
\cline { 2 - 4 } & Control & +Dinochrome A $(5 \mu \mathrm{g} / \mathrm{ml})$ & Inhibition $\%$ \\
\hline GOTO & 8.8 & 1.6 & 81.8 \\
OST & 18.3 & 4.5 & 75.4 \\
HeLa & 17.0 & 4.3 & 74.7 \\
\hline
\end{tabular}

evaluated. Dinochrome A inhibited the growth of GOTO, OST and HeLa cells at the concentration of $5 \mu \mathrm{g} / \mathrm{ml}$, as shown in Table 3. Therefore, dinochrome A exhibits a marked anti-carcinogenic activity and is an effective inhibitor of the proliferation of human malignant tumor cells in vitro.

Some marine carotenoids, such as fucoxanthin, peridinin and halocynthiaxanthin, which possess an allenic or an acetylenic group, exhibit anti-carcinogenic activity. ${ }^{3,4)}$ In this study, we found that dinochromes A and B, which possess an allenic group, also exhibit marked anti-carcinogenic activity. These allenic carotenoids may be valuable as an anti-tumor promoter and chemopreventive agents in chemical carcinogenesis.

\section{Experimental}

General Experimental Procedures The UV-vis and CD spectra were recorded in $\mathrm{Et}_{2} \mathrm{O}$ at room temperature with a Shimadzu UV-240 spectrophotometer and a JASCO J-500C spectropolarimeter, respectively. The EM-MS spectra were recorded using a JEOL JMS-SX 102A and a JEOL JMS-GCmate. The NMR spectra were measured with a Varian UNITY INOVA 500 $\left({ }^{1} \mathrm{H}: 500 \mathrm{MHz},{ }^{13} \mathrm{C}: 125 \mathrm{MHz}\right)$ instruments in $\mathrm{CDCl}_{3}$ with tetramethylsilane (TMS) as internal standard. DQF-COSY, NOESY, HSQC, and HMBC were acquired using the standard Varian pulse programs. HPLC was performed on a Shimadzu LC-6AD instruments with a Shimadzu SPD-6AV spectrometer set at $450 \mathrm{~nm}$. The column used was a Shim-pack Prep ODS with a mobile phase of $\mathrm{CH}_{2} \mathrm{Cl}_{2}-\mathrm{CH}_{3} \mathrm{CN}(2: 8)$. Chemical derivatizations such as acetylation were according to our routine method. ${ }^{15)}$

Extraction and Isolation The red tide was collected by suction of surface water at Fuya dam in Nara Prefecture in August 1995. The red tide cells was harvested by centrifugation and dried over $40^{\circ} \mathrm{C}$ for $2 \mathrm{~d}$. The dried red tide $(500 \mathrm{~g})$ was extracted with acetone-methanol $(7: 3)$. After evaporation of the solvent, the brown green residue was subjected to successively column chromatography on silica gel using an increasing percentage of ether in hexane. The fraction eluted with hexane-ether $(2: 8)$ from silica gel column chromatography was further purified by preparative HPLC on ODS with $\mathrm{CH}_{2} \mathrm{Cl}_{2}-\mathrm{CH}_{3} \mathrm{CN}(2: 8)$ to yield dinochrome A (2) $(71.5 \mathrm{mg})$ and dinochrome $\mathrm{B}(\mathbf{3})(13.5 \mathrm{mg})$. The following six carotenoids were isolated; $\beta$-carotene (1) (40.5 mg), diadinochrome A (4) (13.5 mg), diadinochrome B (5) (1 mg), peridinin (6) $(132.5 \mathrm{mg})$, dinoxanthin $(7)(8.5 \mathrm{mg})$, and diatoxanthin $(\mathbf{8})$ (34 mg).

Dinochrome A (2): A yellow crystal. Yield $71.5 \mathrm{mg}$. EI-MS $\mathrm{m} / \mathrm{z}$ (rel. int., \%): $642[\mathrm{M}]^{+}(26), 624\left[\mathrm{M}-\mathrm{H}_{2} \mathrm{O}\right]^{+}(25), 564(15), 562[\mathrm{M}-80]^{+}(13), 544$ (45), 221 (69), 43 (100). HR-EI-MS: Calcd for $\mathrm{C}_{42} \mathrm{H}_{58} \mathrm{O}_{5}\left(\mathrm{M}^{+}\right)$: 642.4284. Found: 642.4280 . UV-vis: $\lambda_{\max }\left(\mathrm{Et}_{2} \mathrm{O}\right) \mathrm{nm} 400,423,450$. CD: $\lambda \mathrm{nm}(\Delta \varepsilon)$ $220(-3), 250(-6), 275(0) .{ }^{1} \mathrm{H}-$ and ${ }^{13} \mathrm{C}-\mathrm{NMR}$ : Table 1.

Dinochrome B (3): A yellow crystal. Yield $13.5 \mathrm{mg}$. EI-MS $\mathrm{m} / \mathrm{z}$ (rel. int., \%): $642[\mathrm{M}]^{+}(25), 624\left[\mathrm{M}-\mathrm{H}_{2} \mathrm{O}\right]^{+}(23), 564(22), 562[\mathrm{M}-80]^{+}(20), 544$ (50), 221 (60), 43 (100). HR-EI-MS: Calcd for $\mathrm{C}_{42} \mathrm{H}_{58} \mathrm{O}_{5}\left(\mathrm{M}^{+}\right)$: 642.4284. Found: 642.4282 . UV-vis: $\lambda_{\max }\left(\mathrm{Et}_{2} \mathrm{O}\right) \mathrm{nm} \mathrm{400,} \mathrm{423,} \mathrm{450.} \mathrm{CD:} \lambda \mathrm{nm}(\Delta \varepsilon)$ 225 (2), 250 (5), 275 (0). ${ }^{1} \mathrm{H}$ - and ${ }^{13} \mathrm{C}-\mathrm{NMR}$ : Table 1.

TPA-Stimulated ${ }^{32} \mathrm{P}$-Incorporation into the Phosholipids of HeLa Cells Radioactive inorganic phosphate $\left({ }^{32} \mathrm{P}\right)$ was obtained from the Japan Radioisotope Association, Tokyo and TPA was obtained from Shigma Chemical Co. (St. Louis, MO, U.S.A.). HeLa cells (human cervical cancer cells) were maintained as monolayers in Eagle's minimum essential medium, which was supplemented with $10 \%$ calf serum, in humidified air with $5 \%$ $\mathrm{CO}_{2}$. HeLa cells were incubated with the test samples $(25 \mu \mathrm{g} / \mathrm{ml})$ and after $1 \mathrm{~h},{ }^{32} \mathrm{P}(370 \mathrm{kBq}$ per culture) was added, with or without TPA (50 nM). Following $4 \mathrm{~h}$ of incubation, the amount of radioactivity incorporated into the phospholipid fraction was measured. ${ }^{5}$

Assays of the Proliferation of Human Malignant Tumor Cells GOTO (neuroblastoma), OST (osteosarcoma) and HeLa cells were cultured in Dulbecco's modified Eagle's minimum essential medium, which was supplemented with $10 \%$ fetal bovine serum, in humidified air with $5 \% \mathrm{CO}_{2}$ at $37^{\circ} \mathrm{C}$. The cells were subcultured at a density of $4 \times 10^{4}$ cells, in $2 \mathrm{ml}$ of medium, in $35 \mathrm{~mm}$ diameter Petri dishes. Dinochrome A was dissolved in dimethyl sulfoxide $(5 \mu \mathrm{g} / \mathrm{ml})$ and was added to the cultured medium. Following incubation for $3 \mathrm{~d}$, the number of viable cells was calculated. The control culture was treated with the vehicle alone. ${ }^{16)}$

\section{References and Notes}

1) Present address: Research Institute for Production Development, 15 Shimogamo-morimoto-cho, Sakyo-ku, Kyoto 606-0805, Japan.

2) Goodwin T. W. (ed.), "The Biochemistry of the Carotenoids," Vol. 1, Plants, Chapman and Hall, London, 1980.

3) Nishino H., Satomi Y., Tokuda H., Hishino A., Iwashima A., Tanaka Y., Yamano Y., Shibata Y., Torihara M., Tamai Y., Ito M., J. Kyoto Pref. Univ. Med., 100, 831-835 (1991).

4) Nishino H., Mutation Res., 402, 159-163 (1998).

5) Nishino H., Fujiki H., Terada M., Sato S., Carcinogenesis, 4, 107110 (1983).

6) Johansen J. E., Svec W. A., Liaaen-Jensen S., Phytochemistry, 13, 2261-2271 (1974).

7) Englert G., "Carotenoids," Vol. 1B Chap. 6, ed. by Britton G., Liaaen-Jensen S., Pfander H., Birkhäuser, Basel, 1995, pp. 147-260.

8) Akimoto N., Maoka T., Fujiwara Y., Hashimoto K., J. Mass Spectrom. Soc. Jpn., 48, 32- 41 (2000).

9) Marki-Fischer E., Buchecker R., Eugster C. H., Helv. Chim. Acta, 65, 2198-2211 (1982).

10) Cadosh H., Vogeli U., Ruedi P., Eugster C. H., Helv. Chim. Acta, 61, 783-794 (1978).

11) Marki-Fischer E., Buchecker R., Eugster C. H., Helv. Chim. Acta, 67, 461-466 (1984).

12) Buchecker R., Noack K., "Carotenoids," Vol. 1B Chap. 3, ed. by Britton G., Liaaen-Jensen S., Pfander H., Birkhäuser, Basel, 1995, p. 88 .

13) Nishino H., "Carotenoids in Marine Organisms - Metabolism and Biological Activitys-," ed. by Miki W., Koseisya Koseikaku, Tokyo, 1993, pp. 105-113. 
14) Nishino H., Tokuda H., Satomi Y., Masuda M., Bu P., Onozuka M., Yamaguchi S., Okuda Y., Takayasu J., Tsuruta T., Okuda M., Ichiishi E., Murakoshi M., Kato T., Misawa N., Narisawa T., Takasuka N., Yano M., Pure Appl. Chem., 71, 2273-2278 (1999).
15) Fujiwara Y., Maruwaka H., Toki F., Hashimoto K., Maoka T., Chem. Pharm. Bull., 49, 985-987 (2001).

16) Satomi Y., Nishino H., Iwashima A., Torihara M., Tamai Y., Ito M., Anti-Cancer Drug Design, 7, 169-179 (1992). 